\title{
Reclassification of Nonomuraea flexuosa (Meyer 1989) Zhang et al. 1998 as Thermopolyspora flexuosa gen. nov., comb. nov., nom. rev.
}

\author{
Michael Goodfellow, Luis A. Maldonadot and Erika T. Quintanaf \\ School of Biology, University of Newcastle, Newcastle upon Tyne NE1 7RU, UK
}

Correspondence

Michael Goodfellow

m.goodfellow@ncl.ac.uk

\begin{abstract}
A polyphasic study was undertaken to clarify the taxonomic position of Nonomuraea flexuosa DSM $41386^{\top}$. The distinct $16 S$ rRNA gene sequence phyletic branch formed by this strain was equated with nine related monophyletic clades composed of representatives of the genera classified in the family Streptosporangiaceae. The organism produced a PCR product characteristic of this taxon when examined using a set of oligonucleotide primers specific for members of the family Streptosporangiaceae. Strain DSM $41386^{\top}$ could also be distinguished from representatives of the nine genera assigned to this family using a combination of chemotaxonomic, morphological and physiological properties. It is evident from the genotypic and phenotypic data that strain DSM $41386^{\top}$ is misclassified in the genus Nonomuraea and merits recognition as a monospecific genus within the family Streptosporangiaceae. It is proposed that the name Thermopolyspora flexuosa gen. nov., comb. nov., nom. rev. be used for this purpose, with the type strain DSM $41386^{\top}$ (=NRRL B-24348 ${ }^{\top}$ ).
\end{abstract}

Thermopolyspora flexuosa was proposed by Krassilnikov \& Agre (1964) for a group of thermophilic actinomycetes that formed short chains of spores on short sporophores. The species was subsequently associated with a number of other genera, including Nocardia (Becker et al., 1965; Lechevalier et al., 1966), Actinomadura (Cross \& Goodfellow, 1973; Lacey et al., 1978), Micropolyspora (Krassilnikov et al., 1968), Microtetraspora (Kroppenstedt et al., 1990) and latterly Nonomuraea (Zhang et al., 1998). The present polyphasic study was undertaken to clarify the taxonomic position of Nonomuraea flexuosa DSM $41386^{\mathrm{T}}$. The resultant data show that the strain should be classified in a new genus within the family Streptosporangiaceae Goodfellow et al. 1990, emend. Ward-Rainey et al. 1997. It is proposed that the name Thermopolyspora flexuosa be used for this taxon, a proposal advanced by Greiner-Mai et al. (1987) on the basis of chemotaxonomic and morphological data.

Nonomuraea flexuosa DSM $41386^{\mathrm{T}}$ was maintained on glucose-yeast extract-malt extract agar plates (ISP2; Shirling \& Gottlieb, 1966) at $45^{\circ} \mathrm{C}$ and as a glycerol suspension

†Present address: Instituto de Ciencias del Mar y Limnología, Universidad Nacional Autónoma de México (UNAM), CP 04510, México DF, Mexico.

‡Present address: Centro Interdisciplinario de Investigaciones y Estudios en Medio Ambiente y Desarrollo (CIIEMAD), Instituto Politécnico Nacional (IPN), CP 07700, México DF, Mexico.

The GenBank/EMBL/DDBJ accession number for the 16S rRNA gene sequence of Thermopolyspora flexuosa DSM $41386^{\top}$ is AY039253.
$(20 \%, \mathrm{v} / \mathrm{v})$ at $-20^{\circ} \mathrm{C}$. Biomass for the molecular systematic studies was prepared from shake flasks of ISP2 broth incubated at $45^{\circ} \mathrm{C}$ for 15 days and then washed in $\mathrm{NaCl} / \mathrm{EDTA}$ buffer $(0 \cdot 1 \mathrm{M}$ EDTA, pH $8 \cdot 0,0 \cdot 1 \mathrm{M} \mathrm{NaCl})$ and stored at $-20{ }^{\circ} \mathrm{C}$ until needed.

Isolation of chromosomal DNA, PCR amplification and direct sequencing of the purified products of the test strain were carried out after Quintana et al. (2003). An almost fulllength $16 \mathrm{~S}$ rRNA gene sequence was aligned manually with corresponding sequences of representatives of genera classified in the suborder Streptosporangineae retrieved from the DDBJ/EMBL/GenBank databases using the PHYDIT program (Chun, 1995). Evolutionary trees were inferred using the least-squares (Fitch \& Margoliash, 1967), maximumlikelihood (Felsenstein, 1981), maximum-parsimony (Kluge \& Farris, 1969) and neighbour-joining (Saitou \& Nei, 1987) tree-making algorithms from the PHYLIP suite of programs (Felsenstein, 1993). Evolutionary distance matrices for the least-squares and neighbour-joining methods were generated after Jukes \& Cantor (1969). The robustness of the resultant trees was evaluated by bootstrap analyses (Felsenstein, 1985) of the neighbour-joining dataset on 1000 resamplings using the SEQBOOT and CONSENSE options from the PHYLIP package.

DNA from the organism was also examined using the primers $S m 6 \mathrm{~F}$ and $\mathrm{Sm} 5 \mathrm{R}$ which yield a product that is specific for members of the family Streptosporangiaceae (Monciardini et al., 2002). 
Strain DSM $41386^{\mathrm{T}}$ formed the PCR product characteristic of members of the family Streptosporangiaceae when examined with the family-specific set of oligonucleotide primers developed by Monciardini et al. (2002) for the recognition of members of this taxon (data not shown). Comparison of the almost complete 16S rRNA gene sequence (1493 nt) of the tested strain with corresponding sequences of representatives of taxa classified in the suborder Streptosporangineae showed that the organism forms a distinct phyletic line within the evolutionary radiation occupied by the family Streptosporangiaceae (Fig. 1). The organism showed 16S rRNA gene sequence similarities to other members of the family within the range 92.7 to $94 \cdot 7 \%$, values consistent with the assignment of the strain to a novel genus. It is apparent from Table 1 that strain DSM $41386^{\mathrm{T}}$ shows a range of phenotypic properties that distinguish it from representatives of the established genera classified in the family Streptosporangiaceae.

It is evident from present and previous data that strain DSM $41386^{\mathrm{T}}$ can be distinguished from representatives of all of the genera classified in the family Streptosporangiaceae by using a combination of genotypic and phenotypic properties. It is, therefore, proposed that this organism be assigned to this taxon as Thermopolyspora flexuosa comb. nov.

\section{Description of Thermopolyspora gen. nov.}

Thermopolyspora [Ther.mo.po'ly.spo.ra. Gr. n. thermos heat; Gr. adj. poly many; Gr. n. spora a seed; N.L. fem. n. Thermopolyspora the heat (-loving) many-spored organism].

The description is taken from this and earlier studies (Krassilnikov \& Agre, 1964; Greiner-Mai et al., 1987; Meyer, 1989; Kroppenstedt et al., 1990). Aerobic, Gram-positive, non-acid-alcohol-fast, thermophilic actinomycetes which form non-fragmenting substrate and aerial mycelia. Hooked or irregular spiral chains of 4 to 10 warty to spiny ornamented spores $(1 \cdot 2-1 \cdot 5 \mu \mathrm{m}$ in diameter) are arranged in clusters on long, moderately branched aerial hyphae on potato carrot agar; the organism forms a light blue aerial mycelium and a brown soluble pigment on this medium. White to yellowish white aerial hyphae are borne on a lightbrown substrate mycelium on oatmeal agar, but diffusible pigments are not produced. Growth occurs from $\mathrm{pH} 6 \cdot 0$ to $9 \cdot 0$ and from 40 to $60^{\circ} \mathrm{C}$; particularly good growth occurs between 45 and $55^{\circ} \mathrm{C}$. The wall peptidoglycan contains meso-diaminopimelic acid and $\mathrm{N}$-acetylated muramic acid. Glucose and ribose are found in whole-organism hydrolysates from the type species. The type species contains MK9, $\operatorname{MK} 9\left(\mathrm{H}_{2}\right)$ and $\mathrm{MK} 9\left(\mathrm{H}_{4}\right)$ as predominant isoprenologues

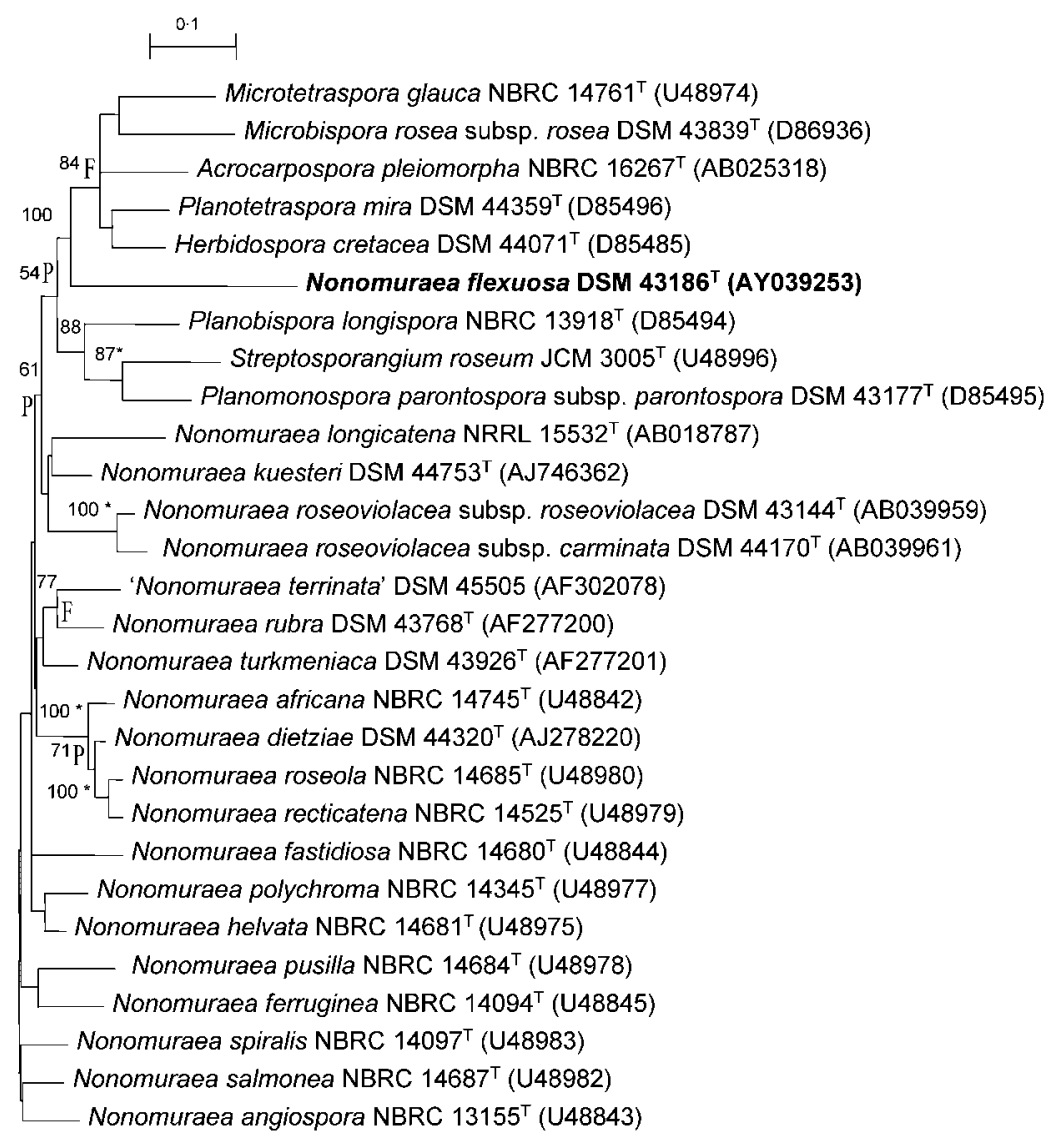

Fig. 1. Neighbour-joining tree (Saitou \& Nei, 1987) based on nearly complete $16 \mathrm{~S}$ rRNA gene sequences showing relationships between Nonomuraea flexuosa DSM $43186^{\top}$ and representatives of genera classified in the family Streptosporangiaceae. Asterisks indicate branches of the tree that were also found using the least-squares (Fitch \& Margoliash, 1967), maximumlikelihood (Felsenstein, 1981) and maximumparsimony (Kluge \& Farris, 1969) tree-making algorithms. Numbers at nodes indicate the levels of bootstrap support (\%) based on a neighbour-joining analysis of 1000 resampled datasets; only values above $50 \%$ are shown. $\mathrm{F}$ and $\mathrm{P}$ indicate branches that were recovered using the least-squares and maximum-parsimony methods, respectively. Bar, 0.01 substitutions per site. 
Table 1. Chemotaxonomic, morphological and physiological characteristics of Nonomuraea flexuosa DSM $41386^{\top}$ and members of the genera classified in the family Streptosporangiaceae

Taxa are indicated as: 1, Nonomuraea flexuosa DSM $41386^{\mathrm{T}}$; 2. Acrocarpospora; 3, Herbidospora; 4, Microbispora; 5, Microtetraspora; 6, Nonomuraea; 7, Planobispora; 8, Planomonospora; 9, Planotetraspora; 10, Streptosporangium. Data were taken from this and previous studies (Greiner-Mai et al., 1987; Goodfellow et al., 1990; Kudo et al., 1993; Tamura et al., 2000; Stackebrandt et al., 2001; Tamura \& Sakane, 2004). The major constituents of the cell wall were alanine, glutamic acid, glucosamine and meso- $\mathrm{A}_{2} \mathrm{pm}(\mathrm{Lechevalier} \& \mathrm{Lechevalier,}$, 1970a). Diagnostic phospholipids: II, phosphatidylethanolanine; IV, glucosamine (with phosphatidylethanolamine and phosphatidylmethylethanolamine variable) (Lechevalier et al., 1977). Wholeorganism sugar patterns of actinomycetes containing meso- $\mathrm{A}_{2} \mathrm{pm}$ : A, arabinose and galactose; B, madurose; C, no diagnostic sugar; D, arabinose and xylose (Lechevalier \& Lechevalier, 1970b). For all taxa, the fatty acid type [saturated fatty acids, unsaturated fatty acids, iso-fatty acids, variable and methyl-branched fatty acids (Kroppenstedt, 1985)] was 3c. +, Present; - , absent; ND, not determined.

\begin{tabular}{|c|c|c|c|c|c|c|c|c|c|c|}
\hline Characteristic & 1 & 2 & 3 & 4 & 5 & 6 & 7 & 8 & 9 & 10 \\
\hline Morphology & $\begin{array}{l}\text { Hooked or } \\
\text { irregular } \\
\text { spiral chains } \\
\text { of four to ten } \\
\text { warty to spiny } \\
\text { ornamented } \\
\text { spores on } \\
\text { aerial hyphae }\end{array}$ & $\begin{array}{l}\text { Club or globose } \\
\text { spore vesicles } \\
\text { on aerial } \\
\text { hyphae }\end{array}$ & $\begin{array}{l}\text { Straight chains } \\
\text { of smooth- } \\
\text { surfaced } \\
\text { spores on } \\
\text { aerial hyphae }\end{array}$ & $\begin{array}{l}\text { Smooth-surfaced } \\
\text { spores in } \\
\text { characteristic } \\
\text { longitudinal } \\
\text { pairs on aerial } \\
\text { hyphae }\end{array}$ & $\begin{array}{l}\text { Spore chains } \\
\text { typically } \\
\text { containing } \\
\text { four smooth- } \\
\text { surfaced } \\
\text { spores on } \\
\text { short aerial } \\
\text { hyphae }\end{array}$ & $\begin{array}{l}\text { Spore chains } \\
\text { or pseudo- } \\
\text { sporangia } \\
\text { formed on } \\
\text { aerial hyphae }\end{array}$ & $\begin{array}{l}\text { Cylindrical to } \\
\text { clavate spore } \\
\text { vesicles } \\
\text { containing } \\
\text { longitudinal } \\
\text { pairs of spores } \\
\text { on aerial } \\
\text { hyphae }\end{array}$ & $\begin{array}{l}\text { Cylindrical } \\
\text { to clavate } \\
\text { spore vesicles } \\
\text { containing } \\
\text { single spores } \\
\text { on aerial } \\
\text { hyphae }\end{array}$ & $\begin{array}{l}\text { Spore vesicles } \\
\text { containing } \\
\text { four spores } \\
\text { on aerial } \\
\text { hyphae }\end{array}$ & $\begin{array}{c}\text { Globose spore } \\
\text { vesicles on } \\
\text { aerial hyphae }\end{array}$ \\
\hline Motile spores & - & - & - & - & - & - & + & + & + & - \\
\hline Cell wall chemotype & III & III & III & III & III & III & III & III & III & III \\
\hline Major menaquinones & $\operatorname{MK} 9\left(\mathrm{H}_{2}, \mathrm{H}_{4}\right)$ & $\begin{array}{r}\mathrm{MK} 9\left(\mathrm{H}_{2}\right. \\
\left.\mathrm{H}_{4}, \mathrm{H}_{6}\right)\end{array}$ & $\begin{array}{c}\mathrm{MK} 10\left(\mathrm{H}_{4}\right. \\
\left.\mathrm{H}_{6}, \mathrm{H}_{8}\right)\end{array}$ & $\operatorname{MK} 9\left(\mathrm{H}_{2}, \mathrm{H}_{4}\right)$ & $\mathrm{MK} 9\left(\mathrm{H}_{2}, \mathrm{H}_{4}\right)$ & $\operatorname{MK9}\left(\mathrm{H}_{2}, \mathrm{H}_{4}\right)$ & $\operatorname{MK9}\left(\mathrm{H}_{2}, \mathrm{H}_{4}\right)$ & $\mathrm{MK} 9\left(\mathrm{H}_{2}\right)$ & $\operatorname{MK} 9\left(\mathrm{H}_{4}\right)$ & $\operatorname{MK} 9\left(\mathrm{H}_{2}, \mathrm{H}_{4}\right)$ \\
\hline Muramic acid type & Acetylated & Acetylated & Acetylated & Acetylated & Acetylated & Acetylated & $\mathrm{ND}$ & ND & Acetylated & Acetylated \\
\hline Phospholipid type & IV & IV, II & IV & IV & IV & IV & IV & IV & $\mathrm{ND}$ & IV \\
\hline $\begin{array}{l}\text { Whole-organism sugar } \\
\text { pattern }\end{array}$ & $\mathrm{C}$ & $\mathrm{B}, \mathrm{C}$ & B & $\mathrm{B}, \mathrm{C}$ & $\mathrm{B}, \mathrm{C}$ & $\mathrm{B}, \mathrm{C}$ & B & B & $A, D$ & B \\
\hline $\begin{array}{l}\text { DNA G }+ \text { C content } \\
(\mathrm{mol} \%)\end{array}$ & 77 & $68-69$ & $69-71$ & $71-73$ & $69-71$ & $64-69$ & $70-71$ & 72 & 71 & $69-71$ \\
\hline $\begin{array}{l}\text { Growth temperature } \\
\text { range }\left({ }^{\circ} \mathrm{C}\right)\end{array}$ & $37-60$ & $15-30$ & ND & $25-55$ & $20-45$ & $20-45$ & $28-40$ & $28-37$ & $28-37$ & $20-50$ \\
\hline
\end{tabular}

*Abbreviations exemplified by MK-9 $\left(\mathrm{H}_{4}\right)$, menaquinone having four of the nine isoprene units hydrogenated. 
and minor amounts of $\mathrm{MK} 9\left(\mathrm{H}_{6}\right)$, phosphatidylethanolamine, hydroxyphosphatidylethanolamine, phosphatidylethanolamine, phosphatidylinositolmannosides, ninhydrinand sugar-positive phospholipids and uncharacterized glycolipids as major polar lipids. It also contains fatty acids rich in saturated, unsaturated and branched chain components, but lacks mycolic acids. The $\mathrm{G}+\mathrm{C}$ content of the DNA of the type species is $77 \mathrm{~mol} \%$. The type and only species is Thermopolyspora flexuosa. 16S rRNA gene sequence data show that the organism belongs to the family Streptosporangiaceae Goodfellow et al. 1990, emend. WardRainey et al. 1997.

\section{Description of Thermopolyspora flexuosa comb. nov., nom. rev.}

Thermopolyspora flexuosa (flex.u'o.sa. L. fem. adj. flexuosa full of turns or windings, tortuous, flexuous referring to the morphology of the spore chains).

Basonym: Actinomadura flexuosa (ex Krasil'nikov and Agre 1964) Meyer 1989.

The description is based on the results of this and previous studies (Krassilnikov \& Agre, 1964; McCarthy \& Cross, 1984; Greiner-Mai et al., 1987; Meyer, 1989; Kroppenstedt et al., 1990; Stackebrandt et al., 2001).

General chemotaxonomic, growth and morphological properties are included in the genus description. Grows well on peptone glucose agar, producing a brown substrate mycelium but no aerial hyphae. Melanin pigments are formed from tyrosine. Growth poor on Bennett's sucrose and glycerol asparagine agars. Degrades agar, casein, DNA, elastin, gelatin, keratin, starch, testosterone, tyrosine, Tweens 20 and 80, xanthine and xylan, but not carboxymethylcellulose, chitin, guanine, hypoxanthine or pectin. Aesculin, allantoin and arbutin are hydrolysed but not urea. Produces arginine dihydrolase, catalase, citrate lyase, $\beta$-galactosidase, $\beta$-glucosidase and oxidase, but not acetoin, hydrogen sulphide, lysine decarboxylase, ornithine decarboxylase or phosphatase. $(+)$-L-Arabinose, $(+)$-Dfructose, $(+)$-D-galactose, $(+)$-D-maltose, $(+)$-D-glucose, $(+)$-D-glycerol, (+)-D-mannitol, (+)-D-mannose, $(+)$ D-sucrose, $(+)$-D-trehalose and $(+)$-D-xylose are used as sole carbon sources for energy and growth, but not dulcitol, inulin, (+)-D-lactose, (+ )-D-melezitose, $(+)$-D-melibiose, myo-inositol, $(+)$-D-raffinose, $(+)$-D-rhamnose, $(+)$-Dribose, $(+)$-D-sorbitol or $(+)$-D-sorbose (all at $1 \%$, w/v). Sodium citrate is used as a sole carbon source, but not sodium oxalate (both at $0 \cdot 1 \%, \mathrm{w} / \mathrm{v}$ ). Grows well on alanine, asparagine, arginine, glutamic acid, histidine, tyrosine and tryptophan as sole nitrogen sources. Nitrates and ammonia salts are not utilized. Resistant ( $\mu$ g per filter paper disc) to chloramphenicol (25), cephaloridine (5), cephalexin (30), cefoxin (30), gentamicin sulphate (2), kanamycin sulphate (30), tobramycin sulphate (10) and penicillin (5 U), but sensitive to cephazolin (30) and gentamicin sulphate (10). Grows in the presence of bile salts $(0.02 \% \mathrm{w} / \mathrm{v})$, crystal violet $(0.00002 \%, \mathrm{w} / \mathrm{v})$, potassium tellurite $(0.02 \%, \mathrm{w} / \mathrm{v})$, sodium azide $(0.01 \%, \mathrm{w} / \mathrm{v})$ and thallous acetate $(0.001 \%$, $\mathrm{w} / \mathrm{v})$, but is sensitive to bile salts $(0.5 \%, \mathrm{w} / \mathrm{v})$, brilliant green $(0 \cdot 0005 \%, \mathrm{w} / \mathrm{v})$, crystal violet $(0 \cdot 00005 \%, \mathrm{w} / \mathrm{v})$, lysozyme $(0.0025 \%, \mathrm{w} / \mathrm{v})$, sodium azide $(0.02 \%, \mathrm{w} / \mathrm{v})$, sodium chloride $(3 \%, \mathrm{w} / \mathrm{v})$, tetrazolium chloride $(0.002 \%$, $\mathrm{w} / \mathrm{v})$, thallous acetate $(0.005 \%, \mathrm{w} / \mathrm{v})$ and novobiocin $\left(50 \mu \mathrm{g} \mathrm{ml}^{-1}\right)$. Produces major proportions of MK-9, MK$9\left(\mathrm{H}_{2}\right)$ and MK-9 $\left(\mathrm{H}_{4}\right)$ (points of saturation: III and VIII) and minor proportions of $\mathrm{MK}-9\left(\mathrm{H}_{6}\right)$ (points of saturation: II, III, VIII). Major fatty acids are iso- $15: 0(12 \cdot 5 \%), 15: 0$ $(5 \cdot 7 \%)$, iso- $16: 0(13 \cdot 8 \%)$, iso-17:0 $(18 \cdot 7 \%)$, anteiso$17: 0(12 \cdot 4 \%)$ and 10-methyl-branched 17:0 (6.9\%) components; minor peaks include anteiso-15:0 (4.3\%), cis-16:1 (2.8\%), iso-2-OH 15:0 (1.4\%), 16:0 (3.4\%), 10-methyl $16: 0(2 \cdot 4 \%)$, iso-2-OH $16: 0(2 \cdot 5 \%), 17: 0$ $(2 \cdot 0 \%)$, iso- $2-\mathrm{OH} 17: 0(3 \cdot 0 \%)$ and $18: 0(2 \cdot 5 \%)$.

The type strain, DSM $43186^{\mathrm{T}}\left(=\mathrm{NRRL} B-24348^{\mathrm{T}}\right)$, was isolated from soil from the Pamir mountains.

\section{Acknowledgements}

E. T. Q. was supported by a studentship from the Consejo Nacional de Ciencia y Tecnologia (CONACYT), Mexico City, Mexico.

\section{References}

Becker, B., Lechevalier, M. P., Gordon, R. E. \& Lechevalier, H. A. (1964). Rapid differentiation between Nocardia and Streptomyces by paper chromatography of whole-cell hydrolysates. Appl Microbiol 12, 421-423.

Chun, J. (1995). Computer-assisted classification and identification of actinomycetes. $\mathrm{PhD}$ thesis, University of Newcastle, UK.

Cross, T. \& Goodfellow, M. (1973). Taxonomy and classification of the actinomycetes. In Actinomycetales: Characteristics and Practical Importance, pp. 11-112. Edited by G. Sykes \& F. A. Skinner. London: Academic Press.

Felsenstein, J. (1981). Evolutionary trees from DNA sequences: a maximum likelihood approach. J Mol Evol 17, 368-376.

Felsenstein, J. (1985). Confidence limits on phylogenies: an approach using the bootstrap. Evolution 39, 783-791.

Felsenstein, J. (1993). PHYLIP (phylogeny inference package), version 3.5c. Department of Genome Sciences, University of Washington, Seattle, USA.

Fitch, W. M. \& Margoliash, E. (1967). Construction of phylogenetic trees. Science 155, 279-284.

Goodfellow, M., Stanton, L. J., Simpson, K. E. \& Minnikin, D. E. (1990). Numerical and chemical classification of Actinoplanes and some related actinomycetes. J Gen Microbiol 136, 19-36.

Greiner-Mai, E., Kroppenstedt, R. M., Korn-Wendisch, F. \& Kutzner, H. J. (1987). Morphological and biochemical characterization and emended descriptions of thermophilic actinomycete species. Syst Appl Microbiol 9, 97-109.

Jukes, T. H. \& Cantor, C. R. (1969). Evolution of protein molecules. In Mammalian Protein Metabolism, pp. 21-132. Edited by H. N. Munro. New York: Academic Press.

Kluge, A. G. \& Farris, F. S. (1969). Quantitative phyletics and the evolution of anurans. Syst Zool 18, 1-32. 
Krassilnikov, N. A. \& Agre, N. S. (1964). On two new species of Thermopolyspora. Hindustan Antibiot Bull 6, 97-107.

Krassilnikov, N. A., Agre, N. S. \& El-Registan, G. I. (1968). New thermophilic species of the genus Micropolyspora. Mikrobiologiia 37, 1065-1072.

Kroppenstedt, R. M. (1985). Fatty acid and menaquinone analysis of actinomycetes and related organisms. In Chemical Methods in Bacterial Systematics, pp. 173-199. Edited by M. Goodfellow \& D. E. Minnikin. London: Academic Press.

Kroppenstedt, R. M., Stackebrandt, E. \& Goodfellow, M. (1990). Taxonomic revision of the actinomycete genera Actinomadura and Microtetraspora. Syst Appl Microbiol 13, 148-160.

Kudo, T., Itoh, T., Miyadoh, S., Shomura, T. \& Seino, A. (1993) Herbidospora gen. nov., a new genus of the family Streptosporangiaceae Goodfellow et al. 1990. Int J Syst Bacteriol 43, 319-328.

Lacey, J., Goodfellow, M. \& Alderson, G. (1978). The genus Actinomadura Lechevalier and Lechevalier. Zentralbl Bakteriol Suppl 6, 107-117.

Lechevalier, H. A. \& Lechevalier, M. P. (1970a). A critical evaluation of the genera of aerobic actinomycetes, pp. 393-401. In The Actinomycetales, pp. 393-405. Edited by H. Prauser. Jena: VEB Gustav Fischer.

Lechevalier, M. P. \& Lechevalier, H. A. (1970b). Chemical composition as a criterion in the classification of aerobic actinomycetes. Int J Syst Bacteriol 20, 435-443.

Lechevalier, H. A., Lechevalier, M. P. \& Becker, B. (1966). Comparison of the chemical composition of cell walls of nocardiae with that of other aerobic actinomycetes. Int J Syst Bacteriol 16, 151-160.

Lechevalier, M. P., De Bièvre, C. \& Lechevalier, H. A. (1977). Chemotaxonomy of aerobic actinomycetes: phospholipid composition. Biochem Syst Ecol 5, 249-260.
McCarthy, A. J. \& Cross, T. (1984). A taxonomic study of Thermomonospora and other monosporic actinomycetes. J Gen Microbiol 130, 5-25.

Meyer, J. (1989). Genus Actinomadura Lechevalier and Lechevalier 1970a, 400 ${ }^{\mathrm{AL}}$. In Bergey's Manual of Systematic Bacteriology, vol. 4, pp. 2511-2526. Edited by S. T. Williams, M. E. Sharpe \& J. G. Holt. Baltimore: Williams \& Wilkins.

Monciardini, P., Sosio, M., Cavaletti, L., Chiocchini, C. \& Donadio, S. (2002). New PCR primers for the selective amplification of $16 \mathrm{~S}$ rDNA from different groups of actinomycetes. FEMS Microbiol Ecol 42, 419-429.

Quintana, E. T., Maldonado, L. A. \& Goodfellow, M. (2003). Nonomuraea terrinata sp. nov., a novel soil actinomycete. Antonie van Leeuwenhoek 84, 1-6.

Saitou, N. \& Nei, M. (1987). The neighbor-joining method: a new method for constructing phylogenetic trees. Mol Biol Evol 4, 406-425.

Shirling, E. B. \& Gottlieb, D. (1966). Methods for characterization of Streptomyces species. Int J Syst Bacteriol 16, 313-340.

Stackebrandt, E., Rainey, F. A. \& Ward-Rainey, N. L. (1997). Proposal for a new hierarchic classification system, Actinobacteria classis nov. Int J Syst Bacteriol 47, 479-491.

Stackebrandt, E., Wink, J., Steiner, U. \& Kroppenstedt, R. M. (2001). Nonomuraea dietzii sp. nov. Int J Syst Evol Microbiol 51, 1437-1441.

Tamura, T. \& Sakane, T. (2004). Planotetraspora silvatica sp. nov. and emended description of the genus Planotetraspora. Int J Syst Evol Microbiol 54, 2053-2056.

Tamura, T., Suzuki, S. \& Hatano, K. (2000). Acrocarpospora gen. nov., a new genus of the order Actinomycetales. Int J Syst Evol Microbiol 50, 1163-1171.

Zhang, Z. S., Wang, Y. \& Ruan, J. S. (1998). Reclassification of Thermomonospora and Microtetraspora. Int J Syst Bacteriol 48, 411-422. 